\title{
Applying Board Race Game to Increase Students' Vocabulary Mastery in Uttayan Suksa Krabi School, Thailand
}

\author{
Risa Octaviani ${ }^{1}$, Ika Handayani ${ }^{2}$, Welliam Hamer ${ }^{3}$
}

${ }^{1}$ English Education Study Program of Teacher Training and Education Faculty, Universitas Sultan Ageng Tirtayasa

${ }^{2}$ English Education Study Program of Teacher Training and Education Faculty, Universitas Sultan Ageng Tirtayasa

${ }^{3}$ English Education Study Program of Teacher Training and Education Faculty, Universitas Sultan Ageng Tirtayasa

\section{ARTICLE INFO}

Keywords:

Applying

Board Race Game

Vocabulary Mastery

\begin{abstract}
The aim of this research was to know the increase of students' vocabulary mastery by using board race game for fifth grade students of Uttayan Suksa Krabi School, Thailand in the academic year 2018/2019. The method used in this research was collaborative classroom action research. The researchers conducted this research from December 2018 until March 2019 in Uttayan Suksa Krabi School, Thailand. In collecting the data, the researchers used observation, test, and documentation. The tests were given in pre-test, post-test 1 and post- test 2 . The researchers analyzed the average score of each test to find out the increase of students' vocabulary mastery after the action was conducted. After the researchers have conducted the action, the students' vocabulary mastery has increased optimally. It could be seen from the score of pre-test that showed 55.3, posttest 1 was 68.6, and post-test 2 was 85.6. After applying the action, the researchers were able to solve the problem in increasing students' vocabulary mastery. The students were able to pronounce, memorize and understand the words based on the context. By using Board Race game in teaching vocabulary, the students could easily understand and memorize the spelling of the new vocabulary. In the teaching process, when the researcher as teacher used game, the students were enthusiastic and enjoyed during teaching learning process. It can be concluded that board race game can increase students' vocabulary mastery. It is suggested to use board race game as the alternative media in teaching learning English.
\end{abstract}

This is an open access article distributed under the terms of the Creative Commons Attribution 4.0 International License, which permits unrestricted use, distribution, and reproduction in any medium, provided the original work is properly cited. @ 2019 Risa Octaviani, Ika Handayani, Welliam Hamer.

\footnotetext{
1 Corresponding author's address: English Education Study Program of Teacher Training and Education Faculty, Universitas Sultan Ageng Tirtayasa, Banten, Indonesia e-mail: risaoctaviaworks@gmail.com

2 Corresponding author's address: English Education Study Program of Teacher Training and Education Faculty, Universitas Sultan Ageng Tirtayasa, Banten, Indonesia

e-mail: ika.handayani@untirta.ac.id

3 Corresponding author's address: English Education Study Program of Teacher Training and Education Faculty, Universitas Sultan Ageng Tirtayasa, Banten, Indonesia

e-mail: welliamhamer@untirta.ac.id
} 


\section{INTRODUCTION}

English has become very powerful language in the world; it becomes an international language that all people must master if they want to compete in the global era, including Thailand. Thailand is one of several countries in ASEAN that uses English as the second language, and it is automatically learning English is a must for students in Thailand. There are four skills in English that have to be mastered, they are speaking, listening, writing, and reading.

In order to have an excellent skill in English, the first step that should be done is mastering the vocabulary. Vocabulary is one of basic aspects in English learning. Without mastering vocabulary, the students will get difficulties when they are communicating with each other. Vocabulary is also the most important one for us to understand some information eventhough it was served in oral or written information. That statement is supported by Hiebert \& Kamil (2005) that generally vocabulary is the knowledge of meaning of words. Vocabulary is used to express ideas, feeling or think or information to people clearly.

Based on researchers' observation in Uttayan Suksa Krabi School, Thailand, the researchers found that the students had complicated problem in using English for their communication. It could be seen that the capability of students in English did not achieve the standard of competency moreover the students cannot read or write even simple word or sentence that their teacher taught to them. Supposedly, as a country that applies English into a second language, their English must be better than Indonesia which makes English only as a foreign language. As a consequence, the teacher has to perform the body gesture, picture or using the Google translator to communicate with the students.

One of the reasons why the students in Uttayan Suksa Krabi School, Thailand have low standard competency in English was because the students' vocabulary mastery was low. There are two factors that their vocabulary was low; internal and external factors. The internal factors are students' motivation, interest, IQ (Intelligence Quotient) and others. The external factors are teaching method, parents, friends, facility, and environment.

In Uttayan Suksa Krabi School, the teacher only used a book and Thai language as media to help students in learning English activities especially in learning vocabulary. One of the methods that can be used is using the games. Games are any games or activities that involve the whole class, sitting in a circle, that the games recycle vocabulary and involve an element of fun." It means that by using the game in teaching English, the students' vocabulary can be increased optimally, moreover the students will learn English joyfully, enjoyably, and get interested.

There are lots of games to help students increase their vocabulary mastery, such as Anagram, crossword puzzle, scrabble, word square, board game, and so forth. In this research, Board Race Game was used to increase the students' vocabulary mastery. Because with board race game, the students can motivate themselves to be confident and go to write the vocabulary in white board and board race is easy game that researchers can apply in elementary school especially for Thailand's students. In this research, the researchers applied Board Race Game to students in fifth grade elementary school at Uttayan Suksa Krabi School, Thailand.

\section{THEORETICAL FRAMEWORK}

\section{Vocabulary}

Hiebert \& Kamil (2005) state that generally vocabulary is the knowledge of meaning of words. Vocabulary is used to express ideas, feeling or think or information to people clearly. In other words vocabulary is important in doing communication both of spoken and written. It represents complex and, often, multiple meaning. It means that vocabulry is a central to language and critical important to typical language learner. Without a sufficient vocabulary, one cannot communicate or express his idea both in oral and written form. Vocabulary is a core component of language proficiency and provides much of the basis for how well learners speak, listen, read, and write. 
From the definitions above, it can be concluded that vocabulary is knowledge of the meaning of words used by human to communicate with other human in verbal and written form. So it is very important to learn firstly before other knowledge and skills of English. In this research, the researchers used the simple vocabulary that students in Uttayan Suksa Krabi School easily found in environment, such as: professions, shapes \& direction and hobbies.

\section{The Importance of Vocabulary}

Vocabulary is the body of words that makes up a language. Without a good knowledge of words and their meanings, both written and verbal communication will be difficult to understand. Thornburry (2002) states that vocabulary means a large collection of items. He adds that learning vocabulary is important because it enriches someone's knowledge of words. The success of the learner in learning a language depends on not only the size of vocabulary but also vocabulary building. Furthermore, Cameron (2001) believes that building a useful vocabulary is central to the learning of a foreign language at primary level. Building vocabulary means both understanding the meanings of words and learning to decode those words. Thus, the students can also enlarge their vocabulary mastery by using vocabulary building.

To show how important the vocabulary is, Bromley (2004) states that vocabulary holds some important roles in teaching learning process. They are as follows:

\section{1) Promoting fluency}

Students who recognize and understand many words read more quickly and easily than those with smaller vocabularies.

\section{2) Boosting comprehension}

Vocabulary knowledge strongly influences comprehension. On a component analysis of comprehension, word meanings were found to make up $74 \%$ of comprehension.

\section{3) Improving achievement}

A large vocabulary means a large of conceptual knowledge which makes academic learning easier. Students with large vocabulary score higher on achievement test then those with small vocabularies.

\section{4) Enhancing thinking and communication}

Words are tools for analyzing, inferring, evaluating and reasoning. A large vocabulary allows for communicating in ways that are precise, powerful, persuasive and interesting.

In conclusion, realizing that the knowledge of vocabulary is very important, learners have to pay a greater attention to the vocabulary teaching especially in Uttayan Suksa Krabi School, Thailand because if students can master vocabulary well, they are be able to increase fluency, boost comprehension, improve achievement and enhance thinking and communication in English.

\section{Vocabulary Mastery}

Vocabulary mastery is competence to know words and meaning. The students are not only expected to know the words but also their meaning. Vocabulary is one of the language aspects which should be learnt. Learning vocabulary is important because in order to be able to speak, write, and listen learners have to know vocabulary first. A person said to know a word if they can recognize its meaning when they see it (Cameron, 2001). It means that in learning vocabulary learners have to know the meaning and understand the words so, they can use it in sentence context.

According to John (2000), vocabulary is knowledge of knowing the meanings of words and therefore the purpose of a vocabulary test is to find out whether the learners can match each word with a synonym, a dictionary - tape definition, or an equivalent word in their own language. In learning vocabulary automatically they have to know the meaning of words themselves and can use it in sentences. 
In brief, vocabulary mastery can be defined as a number of vocabulary (words) in a language which contains information about its meaning, form, and usage in context of communication. It is the basic knowledge that students should master first before mastering English. Vocabulary learning is a principal issue for English learning because it involves the basic building of English sentences. In this research, the researchers study about the process of applying board race game to increase students' vocabulary mastery in Uttayan Suksa Krabi school, Thailand.

\section{Types of Vocabulary}

Thordike and Lorge in (Nation, 1990) define types of vocabulary as follow:

\begin{tabular}{|c|c|c|c|c|c|}
\hline $\begin{array}{c}\text { Types of } \\
\text { Vocabulary }\end{array}$ & $\begin{array}{l}\text { Number of } \\
\text { words }\end{array}$ & Frequency & $\begin{array}{c}\text { Coverage of } \\
\text { text }\end{array}$ & Origins & $\begin{array}{c}\text { Implications for } \\
\text { teaching and } \\
\text { learning }\end{array}$ \\
\hline $\begin{array}{c}\text { High } \\
\text { frequency } \\
\text { word }\end{array}$ & 2000 & $\begin{array}{c}\text { Occur } \\
\text { frequently }\end{array}$ & $\begin{array}{l}\text { About } 87 \% \\
\text { of the of the } \\
\text { running } \\
\text { words in a } \\
\text { text }\end{array}$ & $\begin{array}{l}\text { About half } \\
\text { are from } \\
\text { Latin, } \\
\text { French, or } \\
\text { Greek }\end{array}$ & $\begin{array}{l}\text { Spend a lot of } \\
\text { time on these } \\
\text { words. Make } \\
\text { sure they are } \\
\text { learned. }\end{array}$ \\
\hline $\begin{array}{l}\text { Academic } \\
\text { vocabulary }\end{array}$ & 800 & $\begin{array}{l}\text { Occur } \\
\text { frequently in } \\
\text { most kinds } \\
\text { of academic } \\
\text { texts }\end{array}$ & $\begin{array}{l}\text { About } 8 \% \text { of } \\
\text { the running } \\
\text { words in } \\
\text { academic } \\
\text { texts }\end{array}$ & & $\begin{array}{l}\text { If learners are in } \\
\text { upper secondary } \\
\text { school or in } \\
\text { tertiary } \\
\text { education. } \\
\text { If learners are in } \\
\text { secondary school }\end{array}$ \\
\hline $\begin{array}{c}\text { Technical } \\
\text { vocabulary }\end{array}$ & $\begin{array}{l}\text { About } 1000 \\
\text { to } 2000 \text { for } \\
\text { each } \\
\text { subject }\end{array}$ & $\begin{array}{l}\text { Occur, } \\
\text { sometimes } \\
\text { frequently, } \\
\text { in } \\
\text { specialized } \\
\text { texts }\end{array}$ & $\begin{array}{l}\text { About } 3 \% \text { of } \\
\text { the running } \\
\text { words in a } \\
\text { specialized } \\
\text { text. }\end{array}$ & & $\begin{array}{l}\text { If learners are in } \\
\text { upper secondary } \\
\text { school or in } \\
\text { tertiary } \\
\text { education. } \\
\text { If learners are in } \\
\text { secondary school }\end{array}$ \\
\hline $\begin{array}{l}\text { Low } \\
\text { frequency } \\
\text { words }\end{array}$ & $\begin{array}{c}\text { About } \\
1000-1500\end{array}$ & $\begin{array}{l}\text { Do not occur } \\
\text { very } \\
\text { frequently }\end{array}$ & $\begin{array}{l}\text { About } 2 \% \text { or } \\
\text { more of the } \\
\text { words in any } \\
\text { text }\end{array}$ & & $\begin{array}{c}\text { If learners are in } \\
\text { elementary } \\
\text { school }\end{array}$ \\
\hline
\end{tabular}

Based on the table above, it can be concluded that students in elementary in low frequency words (About 1000-1500) focus in vocabulary mastery and pronunciation. So, that it will be the reference for the researchers in this research.

\section{The Principles of Teaching and Learning Vocabulary}

When teaching or learning vocabulary, several principles should be kept in mind. Cameron (2001) writes down the general principles to help children for learning vocabulary:

1. Teachers can model how to use strategies and draw students' attention explicitly to aspect of strategy use. Example: teacher can show how to find clues to the meaning of a new word in a picture. 
2. Teacher can teach the sub skill needed to make use of strategies. Example: to use a dictionary efficiently requires knowledge of alphabetical order and lots of practice with it.

3. Classroom task can include structured opportunities for using strategies. Example: when teacher reads a story, teachers explicitly encourage prediction of the meaning of new word.

4. Independent strategy used can be rehearsed in classrooms. Example: students can be helped to prepare list of words that they want to learn from a lesson, can show ways of learning from lists and a letter can be put in pairs to test each other.

5. Young learners can be helped to reflect on the learning process through evaluating their achievement. Example: at the end of a lesson, students can be asked how many new words they have learned and which words they needs to learn more about.

Meanwhile, Brown (2004) proposed some guidelines of communicative instructions in teaching and learning vocabulary:

1. Allocate specific class time to vocabulary learning.

2. Help students to learn vocabulary in context.

3. Play down the role of bilingual dictionaries.

4. Encourage students to develop strategies for determining the meaning of words.

5. Engaged in "unplanned" vocabulary teaching.

\section{Advantage of Game}

The game has a benefit in the learning process, game can be used in the process of teaching and learning activities. Tedjasaputra (2001) argues that teacher can use some games as his tools to do observation and evaluation for the students. The game can cause students' motivation and help reduce or eliminate the boredom of students in learning, so students are encouraged to contribute as much as possible to get the best results. According to Tedjasaputra (2001), the benefits of the game are as follows:

1. For the development of the physical aspects in the play, children have the opportunity to engage in activities that involve movement of the body, this will make the body healthy children and the muscles of the body become stronger.

2. For the development of fine and gross motor aspect children aged 3 months of starting to learn to get a toy was near, it is children learn to coordinate eye movements with his hands, indirectly, children learn to per motor movements. Aspects of gross motor skills can be developed through the motions of playing. One example, at the beginning he was not skilled to run, but with a game of chase, then the child's interest to do so and ended up running.

3. For the development of the social aspects of play can be helpful in learning the communication with fellow friends, in this case the child learn to express the content of his thoughts and feelings and learn to understand what was said by a friend, so that social relationships can exist and children can exchange information.

4. For the development of aspects of emotion and personality, children will have a vote against him on surplus or a shortage so as to assist the formation of self-concept and is expected to have a sense of confidence and self-esteem. Through play, children learn how to behave and conduct to working with her, to be honest, brave, generous, and so forth.

5. For the development of cognition, many basic concepts that children learn through play, without realizing it children begin to learn, for example to introduce color and size can be used to play fishing activity which consists of an assortment of colors and sizes. This aspect of cognition is defined as the knowledge, creativity, language skills and memory.

6. To sharpen sharpeness sensing aspects relating to sight, hearing, smell, taste, and tactile need to be sharpened so that children become more responsive to things that are taking place in the 
environment. It is through play, children are expected to be active and critical of the events that appear in the vicinity.

7. For skill sports and dancing physical development as a basis to develop skills in the field of sports and dancing, when the dancing children skillfully perform these activities, he will be more confident, the most important thing is the children loved and happy at the event which will be developed in accordance with interests, talents, and will eventually become a hobby and even a source of livelihood in the future.

\section{Board Race Game}

Board race game is one of the developments of board game as a common game which can be played by using board, table, or floor. Board race game is a fun way for students to practice their English while enjoying some competitions. Board race is a fun game that is used for revising vocabulary, whether it is words from the lesson that teachers have just taught or words from a lesson that the teacher taught last week. It can also be used at the start of the class to get students' activeness. It is a great way of testing what your students have already known about the subjects that the teachers have taught. Learning process for the students which uses board race game and conventional method is different. It can be said that by applying two methods could give the different result in mastering vocabulary. So, it gives us a fact that using board race game can give significant influence in mastering vocabulary (Kusumawati, 2017).

\section{RESEARCH METHOD}

\section{Research Design}

The method used in this research was Collaborative Classroom Action Research. According to Wallace (1998), action research is the systematic collection and analysis of data relating to the improvement of some aspects of professional practice. This research investigated the use of Board Race Game to help the teacher in increasing students' vocabulary mastery. It means that the researchers collaborated with English teacher of Uttayan Suksa Krabi School as an observer and collaborator. The researchers' act was as English teacher who taught English vocabulary by using Board Race Game. Furthermore, according to Kemmis and McTaggart (1992), action research occurs through a dynamic and complementary process; with consist of four essential steps: planning, action, observation and reflection. The subjects of this research were the fifth grade students of Uttayan Suksa Krabi School, Thailand that consisted of 39 students; 15 boys and 24 girls.

\section{Data Collection Technique}

In order to collect the data, the researchers used semi structural interview, test and observation sheet as the instrument to collect the data. The process of teaching and learning was answered by applying interview to both an English teacher and the students, observation sheet and documentations. Besides, to find out the increase of the students' vocabulary mastery, it was answered by applying pre-test and post-test that consisted of 20 items in the form of multiple choice and matching picture.

\section{Data Analysis Technique}

To analyze the qualitative data, this research used data reduction, data display and conclusion. According to Miles \& Huberman (1994), the result of observation was analyzed through data reduction, which included the decoding, etc. meanwhile, data display made the data easily read and draw the conclusion. Furthermore, the result of pre-test and post-test was analyzed quantitatively; to analyze quantitative data the researchers used some formula: The researcher used three techniques in analyzing the numerical data as follow:

1) The researcher sought the average of students' vocabulary score within pre-test and post-test of every cycle by using the formula:

$$
\bar{x}=\frac{\sum x}{n}
$$




$$
\begin{aligned}
& \bar{x}: \text { mean } \\
& \mathrm{x}: \text { individual score } \\
& \mathrm{n}: \text { number of students }
\end{aligned}
$$

2) The researcher sought the class percentage which passed the minimum score of English subject by the formula:

$$
\begin{gathered}
\mathrm{P}=\frac{f}{n} \times 100 \% \\
\mathrm{P}: \text { the class percentage } \\
\mathrm{F}: \text { total percentage score } \\
\mathrm{N}: \text { number of students } \\
\text { (Sudijono, 2008) }
\end{gathered}
$$

3) To know the increase of students' vocabulary pre-test and post-test, the researchers used the standard of six by Gronlund (2009) and presented the data of the comparison between students' score in pre-test and post-test 2 in the table below.

Table of Standard of Six by Gronlund

\begin{tabular}{cc}
\hline Mark & Classification \\
\hline$>8$ & Very good \\
\hline 7 & Good \\
\hline 6 & More than enough \\
\hline 5 & Enough \\
\hline 4 & Bad \\
\hline
\end{tabular}

\section{RESULT AND DISCUSSION}

\section{The Analysis of Preliminary Study}

In this activity, the teacher gave a piece of paper and the students were asked to give a cross of the right answer for vocabulary test. Based on the observation in this activity, most of the students had difficulties in answering the vocabulary test. It could be seen from their vocabulary result. After implementing the pre-test, the researchers assessed the result of the students' vocabulary. From the result, the researchers could calculate the mean of the score of students' vocabulary result by using the following formula:

$$
\bar{x}=\frac{\sum x}{n}
$$

There were $27(69.2 \%)$ students got a good mark, $12(30.7 \%)$ students got a fair mark. The average of students' score of preliminary test was 55.25 points. It meant that the students' vocabulary mastery in the fifth grade at Uttayan Suksa Krabi School, Thailand was still poor.

\section{The Analysis of Cycle I}

The first cycle was teaching and learning process and the assessment at the finishing of cycle I. In the teaching learning process of this cycle, board race game was used as the media to teach students' English vocabulary with the three phases of technique. Then, the researchers gave the test for first cycle. After whole activities had finished, the researchers assessed the students' vocabulary result. From the result, researchers calculated the mean of the students' score of reading result by using the following formula:

$$
\bar{x}=\frac{\sum x}{n}
$$


There were $35(89.7 \%)$ students got a good mark, $4(10.3 \%)$ students got a fair mark. The average of students' score in first cycle was 68.58, It increased 13.32 points from pre-test. The highest score was 100 and the lowest score was 20. From the calculation above, it could be known that there were increase before they were given treatment and after they were given treatment but there were 4 students who did not achieve the test well because they did not pass the minimum score $(\mathrm{KKM})$. It means that the first cycle was unsuccessful enough. Because there were students who still did not pass the minimum score (KKM) from the post-test I, the teacher conducted cycle 2 in order to increase the students' vocabulary mastery. The researchers decided to conduct the next cycle and gave better explanation and exercise in playing board race game.

\section{The Analysis of Cycle II}

In this cycle, the teacher reviewed the previous lesson and gave board race game as the media in teaching vocabulary. In this cycle, students could increase their vocabulary mastery, the researchers still used picture as the teaching aid and board race game, but in this cycle they used worksheet to make students practice at home. Based on the observation, the majority of the students joined the class actively. All activities in the cycle II could run so well. It can be seen from their response, the students were very happy when the researchers said "it's time for game!!". But there were some students who did not pay attention in the middle of teaching and learning process, to make them focus, they asked the students' questions about vocabulary or repeat the explanation of the materials. In the last of meeting, the researchers gave the post-test II. From the result of students' test, researchers calculated the mean of the score by using the following formula:

$$
\bar{x}=\frac{\sum x}{n}
$$

In this cycle, all students passed the standard minimum score (KKM). The highest score was 100, and the lowest score was 65 . The average of students' score in first cycle was 85.51, It increased 16.93 points from post-test 1 . From the calculation above, it could be known that there were improvements before they were given treatment and after they were given treatment. It means the second cycle was successful.

The researcher concluded that the problems have been solved by using board race game for increasing the students' vocabulary mastery because the students were forced to memorize the vocabularies during they played the game, and the worksheet was very helpful to make students practice in their home.

Furthermore, it can be said that applying board race game as media was helpful for increasing students' vocabulary mastery. The researchers also draw the students' improvement in the following table:

Table of Students' Improvement

\begin{tabular}{cccc}
\hline & Average & Percentage & Improvement \\
Pre-test & 55.3 & $69.2 \%$ & - \\
Cycle 1 & 68.6 & $89.7 \%$ & $13.3 \%$ \\
Cycle 2 & 85.6 & $100 \%$ & $17 \%$ \\
\hline
\end{tabular}




\section{CONCLUSION}

Board race game is one of the developments of board game as a common game which can be played by using board, table, or floor. Board race game is a fun way for students to practice their English while enjoying some competitions. Board race game is an easy way to teach students' vocabulary.

The process of using board race game in Uttayan Suksa Krabi School, Thailand went well; it can be seen from the students' enthusiasm in every meeting and the increase in every cycle of the students' score result.

The students' vocabulary mastery increased from the pre-test to the cycle II test. It was shown that the mean of the students pre-test was 55.3, the mean of the cycle I test was 68.6, and the mean of the cycle II test was 85.6. It can be stated that the score continuously increased from pre-test to cycle II test. Therefore, the teaching of English vocabulary by using board race game can increase students' English vocabulary mastery and the students who achieved the standard minimum score (KKM) from the pre-test to post-test II increased significantly.

\section{Suggestion}

After concluding this research, the researchers would like to propose some suggestions to increase English vocabulary mastery.

1) For the teacher

Teacher should have innovative media in teaching especially in teaching vocabulary, such as: using creative teaching aid or using game. Board race game can be a solution to solve the students' problem in less motivation and less vocabulary to keep them cheer up and push them to memorize the vocabulary in the fun way.

Also, teacher should be the students' friend, give them more smiles and listen what they want and what they need that will help them to enjoy our lesson.

2) For the students

The students should apply board race game while in the house with friends or in school in the break time so that it will help them to increase their vocabulary well.

3) For further researchers

This research focuses on increasing the students' vocabulary mastery using board race game. The researchers hope that this finding in this research will be useful for the other researchers in the future especially board race game towards students' vocabulary mastery. This research is expected to be an adequate previous study which can be used by the other researchers to conduct a further research related to the influence of some methods, techniques or games towards students' vocabulary mastery.

\section{REFERENCES}

Bromley, K. 2004. Rethinking Vocabulary Instruction. The Learning and Literacy Spectrum, Vol 14. Spring.

Brown, H. D. 2004. Language Assessment: Principles and Classroom Practices. White Plains, NY: Pearson Education.

Cameron, L. 2001. Teaching Languages to Young Learners. Cambridge: Cambridge University Press.

Gronlund, N.E. 2009. Measurement and Assessment in Teaching. United States of America: Pearson Education, Inc.

Hiebert, E.H. \& Kamil, M.L. 2005. Teaching and Learning Vocabulary: Bringing Research to Practice. Mahwah, New Jersey: Lawrence Erlbaum Associates, Inc.

John, R. 2000. Assessing Vocabulary. Accessed in July 17th 2019. 
Kemmis, S. And Mc.Taggart, R. 1992. The Action Research Planner. Victoria: Deakin University.

Kusumawati. 2017. The Influence of Using Board Race Game towards Students' Vocabulary Mastery at the First Semester of Civil Engineering Study Program, Muhammadiyah University of Metro in Academic Year 2017/2018. Unpublished Undergraduate Thesis.

Miles, M.B. and Huberman, A.M. 1994. Qualitative Data Analysis, a Sourcebook of New Methods. London: SAGE Publication.

Nation, I.S.P. and Read, J. 1990. How Large can a Receptive Vocabulary be? Applied Linguistics 11, 4: 341-363.

Sudijono, A. 2008. Pengantar Statistik Pendidikan. Jakarta: Raja Grafindo Persada.

Sudjana, 2002. Metode Statistika. Bandung: Tarsito.

Tedjasaputra, M. S. 2001. Bermain, Mainan, dan Permainan. Jakarta: Gramedia.

Thornbury, Scott. 2002. How to Teach Vocabulary. UK: Bluestone Press.

Wallace, M.J. 1998. Action Research for Language Teachers. England: Cambridge University Press 